\title{
Globalization, Terrorism and the State
}

\section{Sertif Demir*-Ali Bilgin Varlık**}

\begin{abstract}
:
The main discussion point of this article is to explore the cause-effect relation between the weakening of nation state and the intensification of global terrorism by the influence of globalization. The main thesis of the article is that the malign effects of globalization have considerably weakened nation states or dragged them into a situation in which the security and stability would no longer be sustained as desired. Global terrorism can stem from the adverse effects of globalization, imbalance of power, disparity of players, and power vacuum. Failed states, separatist minorities and radicals use terrorism as warfare in order to counterbalance the power gap or to consolidate their authority. In order to verify/nullify the main thesis, we sought answers for three main issues: consequences of globalization; influence of globalization on terrorism; and lessons learned from terrorism. Our study has come to a conclusion that the most reliable way to cope with the challenges of the new form of terrorism is to strengthen the nation state concept in democratic, laic, social and legal terms.
\end{abstract}

Key Words: Globalization, nation state, terrorism, global terrorism.

\footnotetext{
* Associated Professor, The University of İzmir, the Department of International Relations, sertif.demir@izmir.edu.tr

** Assistant Professor, The University of Esenyurt, the Department of Politics Science and International Relations. He is also strategist at the Institute of 21st Century Turkey, bilginvarlik@gmail.com|
} 


\section{Introduction}

Hardly few other concepts have been argued or associated with each other as globalization and terrorism. And hardly few factors other than globalization and terrorism have eroded the states. During the last two decades and particularly after September 11, 2001 (9/11), terrorism turned into 'global terrorism' and emerged as a new form of threat for both national and international security.

Now we have quite a satisfactory literature, which broadens views but helps little to overcome the issue. This article does not propose any miracle solution to overcome terrorism, which is not argued before, but makes analyses in order to depict basic principles for handling the issue.

The main thesis of the article is that the malign effects of globalization has considerably weakened nation states or dragged them into a situation in which the security and stability would no longer be sustained as desired while promoting terrorism to a global strength. The first complementary thesis is that there appears to be an interrelated and intermingled structure between globalization, terrorism and the state. The second complementary thesis is that the nation state, which was the strongest means to counter global terrorism, is severely influenced by globalization. In other words, global world cannot overcome global terrorism, while underpinning the nation state. The spread of globalization considerably weakened nation states. The third complementary thesis is that terrorism has gained extraordinary power than previously experienced in the contemporary globalized world. So the main discussion point of this study is to explore the correlation between the weakening of nation state and the intensification of global terrorism that might result from the spread of globalization.

In order to verify or nullify the acceptance of the thesis, we tried to answer the following three questions:

- What are the consequences of globalization from security perspective?

- How did terrorism diversify by the influence of globalization?

- What did we learn from the experience of global terrorism?

\section{Theoretical Framework}

Before starting, in order to draw the parameters of level of analysis one needs to underline the approaches and methodologies, which explain the concept of globalization. The easiest but the worst is to make an analysis based upon the results of a phenomenon. This approach, while giving the opportunity to reach direct and practical conclusions, hides the causes and the sources feeding the problem, which enables to reach true diagnosis for defining the issue. So there is no way to answer the question except for arguing the concept of globalization.

\section{Theorizing Difficulty}

Difficulty of theorizing the concept of globalization steams from two reasons. The first is the trouble of access to reliable information; the second is the complex nature of the concept.

Concerning with the access to reliable information about globalization, there occur four basic issues. These are: lack of scientific impartiality, limitation on comprehensiveness, lack of historical background, and difficulty to make synthesis on a live concept.

Firstly, the information created is not objective and polarized between globalists and skeptics. ${ }^{1}$ Both of these approaches are mostly based on results or reflections of globalization rather than the causes. So their analysis turns to a cons and pros struggle which helps little for a dialectical quality of survey. 
Secondly, some surveys which put more emphasis on some aspects of globalization while underestimating the others turn the analysis to "the blind man's definition of elephant"2.

Thirdly, globalization has been imposed as a de facto notion which explains all today's and tomorrow's world but has hardly few about the past. ${ }^{3}$ This approach also conceptualizes the fact on a shallow basis so the real value cannot be assessed properly.

Finally, on the formation of the concept, still additional arguments emerge while some basic thesis has already collapsed. This prevents analyzers to make sound decisions on the subject.

As a conclusion, except for determinist approaches which explain globalization with linear relations, a great majority of analysis agrees with the fact that globalization is multi-dimensional and complex in nature. Unless each ingredient of the concept is assessed and the interrelationship between the factors is defined, it will be very challenging to expound the globalization. At this point we will be content with the affirmation that there is no other complex political system than globalization. ${ }^{4}$

\section{Approaches to Globalization}

Globalization, in general, can be defined as the free movement of capital, goods, knowledge, manpower and services among countries due to the increased technological and scientific improvements and diminished state-centric power. Globalization is the process of integration of cultures. It comes out of the interaction of people from different cultures and societies. Globalization is inherently an economic-originated notion. However, currently it has gained a meaning embracing a political, economical, cultural, sociological and technological formation, which has led to a more integrated world. Ideologically, it was defined as a new phase of capitalism and interrelated with postmodernism.

Having considered this amalgam structure and complex and contentious differences, our aim is to explore the impact of globalization on terror incidents; whether globalization is a catalyzing factor for the increase of terrorism or not. Thus, we have to focus on delineating this interrelation with a theoretical support. In this context, approaches on theorizing globalization could be classified mainly under four titles: 1) novelty, 2) flashback, 3) permanency and 4) transformation. ${ }^{5}$

\section{The Novelty approach}

Mostly suggested by the neo-liberals, the novelty approach asserts that globalization has a unique characteristic as a result of innovative forms of technology, global economy, and communication infrastructure emerged in recent history. Postmodernists also confirm the novelty approach with their motto that has left reality and modern conceptions behind, as well as the world of modernity ${ }^{6}$. According to advocates of the novelty approach, with the demise of Cold War era we experienced the end of history and a new world order. This new world order ignites political, economical and cultural changes, which have never occurred before. The globalization is the end point of mankind's ideological evolution and the universalization of Western liberal democracy as the final form of human government. ${ }^{7}$ Besides Fukuyama, extremists of this approach consider globalization as the first form of global civilization. ${ }^{8}$

The novelty approach lacks historical consistency and it does not explain the globalization which takes place in different parts of the world, except for the West. Additionally it does not even cover the globalization experienced in the social layers of the western world. Furthermore, its prominent thesis that the world economy had never internationalized before is quite open to discussion since not verified by historical and economical data. ${ }^{9}$ Thus we consider it too deterministic to explain the hybrid structure of globalization. 


\section{The Flashback approach}

Generally supported by radical leftists and some conservatives, the flashback approach suggests that today's globalization overlaps with the world order prior to World War I. The collapse of bipolar international environment has rotated the flow of capital and trade to the level before the World War I. According to supporters of this approach the world has flashed back to the era of the ferocious imperialistic competitions, and the contemporary situation under the leadership of US is a new form of the $18^{\text {th }}$ and $19^{\text {th }}$ centuries' globalization which took place in the lead of UK. ${ }^{10}$

The flashback approach repeats the novelty approach's shortfall on historical consistency, by disregarding the fact that no social formation could be reiterated. Particularly, conservatives' attempt to impose the globalization as a moral value rather than historical phenomena is a major contradiction with the reality and is too subjective to be scientific. Thus, we consider it too holistic to explain differences of contemporary globalization.

\section{The Permanency approach}

The permanency approach affirms that there have never been sudden drastic changes in the mankind history, neither has globalization. Globalization is not an unexpected legendary event as globalists present but, is an operation of nonbelligerent logic of capitalism and geo-economic imperialism. According to backers of the approach, globalization is the subjective volitional ideological project of transnational corporations and international finance organizations rather than an objective reality. ${ }^{11}$ Capitalism is a hegemonic global system in nature and sees the world as a whole economic structure since its evolution. ${ }^{12}$ Generally supported by skeptics, the approach suggests that today's globalization is not different than the globalization in 1850 and 1910 and limited geographically with the north hemisphere and functionally with financial markets. ${ }^{13}$

Although the permanency approach uses an acceptable historical methodology, and defines successfully the limits of contemporary globalization, it neither estimates the dramatic and systematic shift after the big bang of 1970's and 1980's globalization nor appropriately reads the importance and distinctive roles of technology and communication. The approach could also be criticized by being economically centric.

\section{The transformation approach}

The transformation approach mostly supported by social scientists accepts that a historical shift has been experienced. Transformationists do not reject the notion that historical changes result from a series of previous events. Accordingly, the globalization process, started at the beginning of $19^{\text {th }}$ century and stalled by the world wars and the Cold War, has revived as from 1970's, has been accelerating and turning to a permanent structure. According to the transformation approach advocates, world economies and communication systems have established a structure in which peoples, cultures and states have intermingled throughout the modern times; and recent developments have shifted us to a new qualitative dimension. In several ways globalization is a new and dramatic progress as well as being part of a historical process. At the last phase of globalization a new global way of cooperation has superseded previous center-periphery relationship while an anachronism has been exacerbating. ${ }^{14}$

\section{An Assessment of the Approaches to Globalization from Security Perspective}

Contrary to the novelty approach, the transformation approach advocates reject that the nation state has ended, but maintain that the relationship between the stakeholders of the authority has been reorganized according to the new world order. They reject the flashback approach's hypothesis of "nothing has changed", but deem globalization as a derivative of the Illumination Age of the Western World. According to that, globalization is the new realization of modernity concept on social, 
economical, cultural and philosophical dimensions throughout the world. Different than the permanency approach, they believe that globalization is not only a temporary dictation of the capitalists but an unavoidable structure which shapes -to some extent commands- today's world. So, some measures to be taken could mitigate malign effects while creating opportunities to benefit from the globalization. On the other hand, as being less holistic than the flashback approach, the permanency approach provides some useful data for comprehensive assessments on security perspective of globalization.

After these comparisons, we reach to the conclusion that the comprehensive and the transformation approaches give relatively more appropriate data to analyze the consequences of globalization from security perspective than the other too deterministic and more holistic approaches.

\section{Implication of Globalization from Security Perspective}

Globalization has a complex and amalgam structure, and has economical, technological, historical, political, social and other dimensions, and numerous effects on security. Contrary to its advantages, chances and positive influences, one can hardly comment optimistically on its effects on security, because of two reasons: The first is its deteriorating influence on nation state's power; and the second is its relationship with terrorism.

\section{Deteriorating Influence of Globalization on Nation State's Power}

Consequences of globalization could be summarized basically on two folds; the first is the chaos of the new world order, which provokes instability; the second is the erosion observed in the nation state due to globalization. The former is concerned with historical, social, economical, technological, military and other imbalances moved by the globalization. The latter is a matter of structural, institutional and processional transformation of the anarchic international environment as well as the security atmosphere in which dramatic power shifts occurred against monopoly of the state. In other words, as stated by Keohane and $\mathrm{Nye}^{15}$, globalization and economic interdependence has changed basic parameters of conventional [Westphalian] system of states" to an anarchic environment in which multiple channels of interdependence between new international actors added to the states. These two groups of consequences of globalization are related with each other and establish a complex and hybrid structure.

\section{The Chaos of the New World Order}

From historical perspective, globalization has always been a power-based process of the hegemonic states and capitalism to shape and rule the world. Historically, this power had always been projected by the West: The first wave of globalization started with the "Exploration of the New World" and was institutionalized as colonialism during the period of 1480-1750. The second phase started just before the "Industry Revolution" and was institutionalized as imperialism or new colonialism during 1750-1914 era. The third phase started 1914, even though hampered by world wars and their aftermaths; continued with the impulse of multinational corporations' championship that started in 1970's; climbed with the "Communication Revolution" in 1980's; and reached its peak with the "New World Order" after Western World's victory over the East in 1990's. ${ }^{16}$

Social ataxias of globalization include historically rooted philosophical, psychological and cultural features. Social observations also vary depending on where you are, where you are looking and the period of time you are observing. From this context, any evaluation made by those who are not from the leading side of globalization ("unglobalized" and "non-leading globalizers"), the "struggle of the West with the rest" would be a better term than the "clash of civilizations". 
Globalization has been imposed as the highest level of civilization and morality by those who are leading globalization (globalizers) but from unglobalized and non-leading globalizers' perspective, that does not drop the tension and bilateral phobias between the cultures and the religions, fostered by globalization.

From economic perspective, although economically it helps to increase gross global product, the amount of direct international investments, the role of transnational corporations, liquidity of capital and global finance, it worsens the gap between rich and poor, and weakens states' defensive apparatus to protect national economy and to localize labor force within the national boundaries. Wealthy nations while preserving their quotas, economic subventions and incentives for their homeland segments and conducting economic rescue operations for failed allies, belligerently apply "bitter prescriptions" or "shock therapies" for a "free market economy" on the "liberated" states ${ }^{17}$. So globalization neither means equality in chances and opportunities nor just and even distribution of wealth.

Differentiation on production and service, information and military technologies has shifted social layers, and reduced competitiveness of developing economies. Countries other than those which are located at the core, are to suffice a peripheric or semi-peripheric location with low profit and inadequate efficiency at the best or to be ousted from the economic race.

From technological perspective, there is no doubt that globalization promoted humankind to reach post-industrial layer of technology which is called "Information Age". The good news that globalization brought along "democracy of information" is still debatable since information and knowledge portals are still in the monopoly of some centers, but spoiled information is everywhere. "Global Village" thesis forwarded by Marshall McLuhan in 1962, still needs to be proved against the numerous data attesting that basic health, communication, and education technologies are still luxury in most regions of the world.

Developments in the military technologies, while creating huge gaps between the conventional forces of the Western World and their potential rivals, have increased desire for weapons of mass destruction, for using terrorism militarily and for other asymmetric warfare methods, which violate international law and poses fatal threats to the security of the anti-Western states.

\section{The Erosion Observed in the Nation State due to Globalization}

As noted above, historically globalization has followed three phases. During the first and the second phases, central authorities always hampered or at least canalized the free trade market flow, and dominant powers did not want to lose their authority. In the third phase, particularly after the collapse of bipolar world system, liquidation of capital, financial operations, interventions of international financial organizations in national economies have either hampered or softened central authorities' dictations on economy. The third phase has promoted a less bloodshed type of free trade, which is backed by organizations, systems and procedures rather than hegemonic states' hard power.

It is generally accepted that globalization has reduced nation state power. During the last phase of globalization, it was discussed that nation states would eventually disappear from political life and new form of power centers will replace them. However, recent developments have not sufficient evidence to prove that nation state fades as supporters of globalization expected. Instead, it is argued that the nation state is "neither retaining its primacy nor disappearing but becoming transformed and absorbed into a TNS (Trans-National State) ${ }^{18}$. The emerging TNS is composed of international institutions like World Bank (WB), International Monetary Fund (IMF) and Bank of International Settlements (BIS), European Union (EU), World Trade Organization (WTO) and North American Free Trade Agreement (NAFTA). Nation states continue to carry out important functions, but these have been increasingly transnationalized, as macroeconomic policy becomes increasingly 
focused on appropriate fiscal, monetary, trade and investment policies that allow for the intensification of transnationalization. Thus, welfare and developmental states have been transformed into neo-liberal states. ${ }^{19}$

More than any of its impact, the complex structure of globalization not only has inflated disparities and contrarieties but also created paradoxical shifts on the parameters of the world system that we knew. Globalization, while promoting standardization, global affinity, unity and intermingled interdependency on the one hand, provokes localization, disparity, definition of identities on a smaller level than nation on the other hand. ${ }^{20}$

Influences of globalization have not been unified because of historical, social and economic diversities throughout the world. For example, while shaping the Western World particularly Europe as unified not only on value base but in economic and political dimension, globalization had fragmented some nation states into ethnic and religious factions in the rest of the world. The last wave of globalization concurrent with the collapse of Iron Curtain helped masses to question not only the boundaries of state authority and legitimacy of the ruling regimes throughout the world, but also citizen, women and minority rights. Diffusion of multi-ethnic national states left the ground to ethnic and religious unities mostly after fierce fightings, atrocities and genocides.

Policies and strategies like "preventive strike", "crusade", "just war" and "humanitarian intervention", which created polarization among cultures, have not only made arguable the classical use of force concept accepted by the international law, but also set new processes and procedures which eroded nation states' hegemonic power.

New players like anti-globalist or counter-state civil society organizations, NGOs and GONGOs (Government Oriented/Backed NGOs) loosened previously established firm ties of the states on the society and shifted anarchic political arena to a more chaotic atmosphere than ever. Emerging as a new sector of big capitals, the media fastened its position as the forth power -after legislation, execution, and judiciary- and turned out to be a means of information warfare.

In addition to the negative influences of globalization, almost all positive impacts of globalization have also deteriorated nation states' control over society. The erosion within local cultures and traditional social bonds has underpinned nation state's authority, while diminishing mental boundaries and increasing transparency of physical international borders and the importance of individualism.

So, regardless of being good or bad, globalization has eroded nation sate's power, and transformed the international environment into a multi-dimensional and multi-cultural atmosphere in which nation states are no longer the main determinant actors. Now, we are experiencing a world in which power could no longer be identified as a linear, hierarchic, state-oriented and state-controlled phenomenon. This dramatic change on concept of power has transformed the role of the nation state during the last phase of globalization.

As a result of this assessment we concluded that the new world order in the last phase of globalization, and its consequences have dramatically changed and weakened nation state's power and its control on internal and external policy. ${ }^{21}$

\section{The Relationship between Terrorism and Globalization}

The linkage between increased terrorist activities and globalization can hardly be proven due to some difficulties. First, it is difficult to state that globalization is the only driven-factor behind the outnumbered terrorism. Second, violent methods aiming at political aspirations have existed before global process. There is no clear-cut finding that delineates or justifies this thesis. However, it can be 
argued that globalism has created some conditions that can trigger the use of violence in order to realize political aims. As globalization is deemed the culprit of the uneven distribution of wealth, growth of poverty, de-emphasis of nation states, and regional impoverishment, the violence or use of power against the globalism can be applied and these acts can be assessed as terror by global factors. In this case, human security is offered by Alan Miller ${ }^{22}$ as a protection against those marginalized by globalization:

"Security from terror can only be assured if human security is provided for those marginalized by globalization, and development can only be sustained if those in the most need are empowered to claim their right to development and the satisfaction of their rights to an adequate standard of living."

There are many views regarding the connection between globalism and terrorism. Nassar ${ }^{23}$ dissects globalization through the concepts of interdependence, liberalization, universalization, westernization, and capitalism. He shows the relationship of globalization with violence and advances a coherent definition of terrorism (that includes actions by governments) based on material reality. Terrorism is perceived "in a complex political context". Central to the theme is the thesis of "the migration of dreams" as a consequence of cultural and technological globalization and "the migration of nightmares" as a consequence of global violence and terrorism. Here, violence is understood in broad terms: colonialism, transnational corporate exploitation, and the US imperial project are all faces of violence and terror. The author looks at the root causes of terror and considers that globalization has increased the gap between rich and poor, which, in turn, has enhanced the prospects of violent responses. State-sponsored terrorism also has enhanced those prospects.

As the conclusion, globalization is a matter of historical development, which establishes Western values, institutions, interests, and security conditions while spreading out the capitalist economic, social and political order with the help of monetary, technological, and military power. Globalization is a fact and a historical process with its pluses and minuses but terrorism is a moral defect and a crime against humanity. Any organization uses terrorist acts cannot be justified for any reason. Nothing legitimizes terrorism; it cannot be a compelling excuse neither to civilize savages nor to fight against superior powers. Simply murder of innocent people is not excusable. ${ }^{24}$ For sure terrorism is older than globalization so there is no direct relation between them.

Based on the knowledge we have received up to this point, we reach to the conclusion that there is a cause-effect relationship between globalization and instability. This stems from the adverse effects of globalization, the imbalance of power, disparity of players; and power vacuum. All these three factors have created a fragile environment for stability as well as a favorable ground for terrorism. Globalization, while breaking the walls of the nation state and supporting disparities in the societies on the one hand, has alienated those who are not part of it and provoked the tendency of violence. For sure globalization has created security concerns more than the stability it produced. Failed states, minorities and separatists used terrorism to counterbalance the power gap or to solidify their authority. Collapse of bipolar security environment and impoverishment of the nation-state as a consequence of globalization have exacerbated instability. As one of the most severe element of instability, terrorist organizations gain ground by exploiting consequences of globalization and pose threat by using advantages of globalization. Therefore there is an indirect relation between globalization and terrorism. 


\section{How Did Terrorism Turn Into Global Terrorism?}

The concept of terrorism is one of the most disputed terms in social sciences. A definition that will be widely accepted is still lacking. The problem of defining the term 'terrorism' is well known and has been examined extensively. Apart from the problem of distinguishing it from guerrilla warfare, crime or mad serial killers, the well-known phrase 'one man's terrorist is another man's freedom fighter', is often used to highlight the problem of implying a moral judgment when classifying the term 'terrorism'. ${ }^{25}$ If one identifies with the victim of the attack, then it is considered terrorism, but if one can identify with the perpetrator it is not. ${ }^{26}$

There are many diverse definitions about terrorism. However, terror is often defined as a threat or actual use of violence by a non-state actor against civilians in pursuit of political goals. Leonard Weinberg, Ami Pedahzur and Sivan Hirsch-Hoefler ${ }^{27}$ examine 73 definitions of terrorism from 55 articles in three leading academic journals on the topic, and come to the conclusion that "[t]errorism is a politically motivated tactic involving the threat or use of force or violence in which the pursuit of publicity plays a significant role." 28

Local, regional or any kind of terrorism prefers to use the advantages of globalization and exploits its vulnerabilities somehow. These acts could not be named as global terrorism unless they create global affects. Devastating economic imbalances have always contributed to terrorism. What made it globally critical is states' impoverished capabilities to intervene in economy in order to reduce the gap between rich and poor.

Tremendous technological developments that have a great impact on tactics of terrorists cannot be underestimated but this is not new as perceived. However, states' broken monopoly over security technologies after the Cold War and particularly on weapons of mass destruction (WMD) and information technologies in 1990's has created risks prone to global instability.

Contrary to some analysts, global terrorism is not terrorist acts against global powers. Terrorism, which uses advantages and exploits vulnerabilities of globalization and creates global effects is called global terrorism. So global terrorism is not a new phenomenon but contemporary terrorist acts have more global effects than ever, since the last phase of globalization distinctively exceeds borders, shrink unities, hampers the apparatus to prevent non-state actor source of violence more than previous versions of globalization. So we cannot live with the assumption that we can overcome contemporary global terrorism with the old-fashioned counter-terrorism methods of 1960's.

Returning back to the approaches to globalization we can examine their consistency with the concept of global terrorism. The novelty approach fails since global terrorism is not a matter of today as globalism itself is not, either. The Flashback Approach fails since today's global terrorism is not same as the one in the $18^{\text {th }}$ and $19^{\text {th }}$ centuries. The Permanency Approach's assumption that contemporary globalization is the continuation of previous waves and no big shift is possible fails to read the extraordinary flow of global terrorism. Compared to other approaches the transformation approach seems the least erronious, because terrorism has been diversified in the way this approach defines globalization.

Contemporary terrorism is global in nature since it uses advantages and exploits vulnerabilities of globalization and creates global effects. As we have mentioned above there is an indirect relationship between globalization and global terrorism. So without defining its complex and amalgam structure, and economical, technological, historical, political, social dimensions, one could neither be able to assess global terrorism nor have the chance to overcome it.

For efficiently fighting against global terrorism any strategy should follow three phases. The first is to consider all components of globalization and their impacts on stability as well as terrorist organization(s). The second is to assess the security environment. The third is to analyze the 
apparatus and the system required to prevent global terrorism. This affirmation is a version of constants of strategy since Sun Tzu; known as "enemy, terrain and friendly forces". ${ }^{29}$ These three factors could also be used to develop a strategy for fighting against terrorist organizations. Here the authors will not make an analytical survey on each of these factors but try to explain the nodule, with which all causes and results are directly connected.

The common denominator of the reason for the transformation of terrorism into a global context and the way of fighting against global terrorism lay in the changing role and weight of the state. Globalists consider nation states as an obstacle for globalization and suggest that life cycle of nation state ended and "market state" 30 emerged as the main actor to counter today's and tomorrow's expectations.

Market state's prominence is another subject of discussion. Here we will be contented with reminding that market state is not a new phenomenon but a $21^{\text {st }}$ century version of Holland's merchant state model, which was established to enable global spread to maximize profits of VOC (Vereinigte Oost-Indische Compagnie) in the second half of the $16^{\text {th }}$ century. Holland's merchant state model was an upgraded version of Italian city-states of $15^{\text {th }}$ century with an exception of being backed by military power. ${ }^{31}$ In spite of its benefits for a series of firms, exchange market and Amsterdam Bank, Holland's merchant state was not long lasting because of its defects not matching with a nation state. Additionally starting from the Reagan administration, the near past has shown us that free market economy does not regulate the security conditions.

\section{Probabilities of Globalization-Nation State-Terrorism Trivet from The Security Perspective}

There are two basic, one complementary possibilities which explain the interrelation between globalization, nation state and terrorism from the security perspective: The imbalance of power between terrorism and nation state could result from either a dramatic impoverishment of the nation state or an extra ordinary power gain of terrorism to an extent which differentiated its regular form. The complementary possibility is the situation in which both occurred simultaneously.

So these affirmations give us a three-layer model, which has a vicious circle characteristic in nature:

- In the first layer, failed states and crime organizations use terrorism as warfare; nation-states cannot localize and/or mitigate and/or overcome terrorism; terrorism exploits advantages of globalization and creates global influence. So, terrorism mutated.

- In the second layer, globalization directly underpins nation-state; nation-state fails; and terrorism pervades globally. So, globalization weakens nation-state.

- In the third layer, globalization causes instability; instability weakens the nation-state; nation-state cannot overcome internal terrorism; and terrorism strengthens globally. So, terrorism mutated and nation-state weakened.

\section{Empiric Clues between Intensified Terrorism and Globalization}

The data obtained from RAND provides some clues about the relation between the globalization and terrorist activities. The number of international terrorist activities covers the data between 1968 and 2009 which coincide with the third globalization period in which the nation states started to lose their power due to increasing globalization impact. The main thesis is that the global terror has increased as nation states can hardly sustain stability and security as their powers started to decline. The data indicates that global terrorism follows an increasing trend starting from the late 1990s where globalization has reached its peak. The correlation between terrorist incidents and globalization 
provides an evidence to justify our thesis. It is a viable data that can prove the correspondence between increased terrorism and globalization. Of course, there are several motives behind the increasing global terrorism as explained in previous paragraphs. Social, political, cultural, religious extremist, ethnical and psychological factors are some driven-factors that trigger the terrorism to reach any goal. However, the correlation among the weakening of nation-state, the spread of globalization and the intensification of global terror all have coincided at the end of 1990s. This overlapping can, in any case, support the hypothesis as globalization considerably weakened nation states or transformed them in a shape by which the security and stabilization would not be sustained as desired. ${ }^{32}$

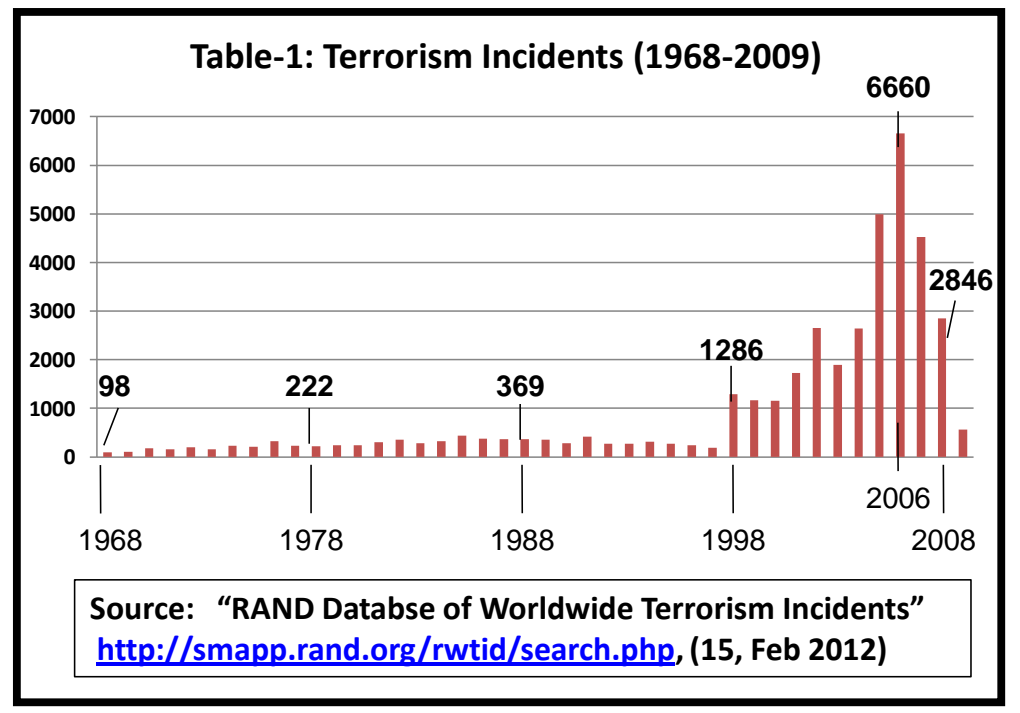

Data given on Table-1 clearly indicates that there is a growing trend in terrorism incidents starting from 1998. When we compare the average of events during the period of 1968-1997 (Av.Incid. ${ }_{1968-1997}=267$ ) with the period of 1998-2009 (Av.Incid. ${ }_{1998-2009}=2677$ ), we reach to the conclusion that there is a 10-fold increase in terrorism events. (RAND's permission has been taken through electronic mail to publish those numbers)

This dramatic change may be interpreted in various ways, however the most probable reasons for such a picture coincide with the hypothesis of this article. Such an extreme increase could be a strong indication of:

- Either a drastic decline in the power of nation state - as confirmed by historical developments and theoretical framework mentioned above as well as empiric data shown on Table-1.

- Or a conceptual dramatic change in the use of terrorism.

Lessons learned from the recent experience of terrorism give us clues on the transformation of terrorism.

\section{What we Learned From the Experience Of Global Terrorism}

No shape of international architecture could be more secure than the one with prosperous nation states. Although the direct strategy seems to be reinforcement of the nation state for fighting against global terrorism, this would be hardly possible while globalization underpins the central authorities. Considering the conflicting interests of nation state and globalization and cause-effect relationship between globalization and terrorism, there occurs a decision point ${ }^{33}$ for globalization. Here, the matter 
is to accept to which extent power should be shared with the nation state or terrorism should be tolerated. From the perspective of imperialistic logic of capitalism, terrorism is acceptable unless it threatens profits. Additionally terrorist acts could be helpful for dominant powers to enlarge their global presence. From realistic perspective globalization is unavoidable and indispensable and terrorism is uncontrollable as long as it can see fertile ground in the soil of weakened states. We claim that 9/11 terrorist attacks would not be so effective if the state apparatus in the area where al-Qaeda stationed were strong enough at least to detect the planning phase of the terrorist assault.

As in his speech on September 27, 2001, President Bush noted that 9/11 terrorist attacks were not only an event but also an experience of the new form of terrorism. ${ }^{3435}$

"This is not a conventional war that we're waging. Ours is a campaign that will have to reflect the new enemy. There's no longer islands to conquer of beachheads to storm. We face a brand of evil, the likes of which we haven't seen in a long time in the world. These are people who strike and hide; people who know no borders..."

So $9 / 11$ terrorist attacks have to be handled as a decision point to fight against terrorist networks rather than engaging in a retaliatory operation which violates international law. ${ }^{36}$

9/11 terrorist attacks explicitly showed three aspects:

- The first is that the threshold either to isolate or to limit terrorism has been exceeded and terrorism can hit any target any time anywhere. We are not at a point to localize terrorism. So we need to shape the security environment in such a way which globalization and the nation state could live together.

The second is that terrorism is not anymore limited with only symbolic targets and has the capacity to use all advantages of high technologies. Terrorism has transformed into a new warfare in which all forms of non-conventional war tactics, techniques and procedures are used. So we need to develop new strategies against global terrorism.

- The third and the most dangerous is that terrorist organizations are supported by the masses or countries ${ }^{37}$ which perceive themselves as the victims of globalization by religious, ethnic or other motivations. Thus, contemporary global world is more vulnerable than ever. So we need to prevent clash of civilizations.

The first two aspects are the ones that could be overcome by protective measures. These measures require an internationally coordinated seamless robust military concept. In order to counter the first aspect of terrorism the concept should downgrade the military power of terrorism by eliminating its capabilities of exploiting globalization. In order to counter the second aspect of terrorism, the concept should also cover the fact that terrorism has transformed to a new form of warfare slipping off its traditional limited and symbolic characteristic.

The third is the main area of concern for politics, ethic and social-psychology together with security measures, military operations and international cooperation since contemporary terrorism can sustain its public support despite its attacks on innocent civilians and terrorist organizations have left their regular chain of command structure.

Laqueur $^{38}$ argues that modern terrorists are more ruthless than their historical counterparts were. He says modern terrorism has been typified by indiscriminate violence and the international targeting of the civilian population. Modern terrorists strike at governments by killing their citizens. For the contemporary terrorists, starting from the mid of 1990's, as long as they do not lose support from their population, more innocent victims mean more tears for the sake of their power. The increasing trend in religiously inspired terrorist organizations ${ }^{39}$ and the support or at least sympathy they have gained indicate that the new form of terrorism is fertilized by religious animosity. 
The dispersion of terrorist organizations has created new form of terrorism. ${ }^{40}$ In this new form, terrorist organizations are decentralized in conduct of operation, so decision makers of terrorist organizations say what to do, local cells plans and execute terrorist attacks regardless of any organizational linkage.

Unless terrorism is ousted politically, ethically and psychologically, military measures could have slim chance of success. So struggle against terrorism should concentrate on cutting the support to terrorism to the utmost.

Developments after 9/11 terrorist attacks taught us three lessons:

- The first is that humanity's stance against terrorism should be in consent; moreover acts against terrorism should be unilateral rather than multilateral. ${ }^{41}$ In other words, "yours are the freedom fighters, mines are terrorist" sayings only embolden criminals against humanity and increase the innocent losses; so this approach is complicity of the crime. National and international institutions should go after terrorists and those who harbor or support terrorism, and terrorist networks with the appropriate legal, financial, judicial, and political instruments. ${ }^{42}$

- The second is that neither negotiating with terrorists nor behaving the way they understand does help to solve the problem. Because murder is inexcusable and we cannot detach ethics form the policies and the experience of terrorism ${ }^{43}$ and the way terrorists' interpreted Jihad could not be nourished better than the Crusader approach.

- The third is that there is no way but winning hearts and minds of the people ${ }^{44}$ even prone to but not involved in terrorist acts. Isolations, exclusions and labeling masses as terrorist do not help us but the enemy. Compassion and respect will let terrorism armless. So there has always been a way to separate the "fish" from "water". ${ }^{45}$

According to Spencer ${ }^{46}$, after 9/11 new terrorism concept has widely been accepted. He believes that there is something inherently new about the terrorism of today. This includes a fanatical religious motivation, excessive indiscriminate violence together with the possible use of WMDs, an increasing independence from state sponsors as well as a new network structure helped by communications technology and new amateur terrorists who only come together in ad hoc groupings.

Considering the essential strategy against global terrorism mentioned above, we clearly see that this new form of terrorism first and foremost should be isolated from its integral parts like; public support, financial power, abilities to exploit globalization etc. ${ }^{47}$ From the strategic point of view the center of gravity ${ }^{48}$ on fighting against global terrorism is to cannibalize it by using the asymmetric powers of nation state. The point terrorism reached counters many of our military capabilities but the values that nation-state has.

What we did not take as a lesson from global terrorism experience is that we have no other chance than reinventing value of modern nation state identity, which has social responsibility, laic stance, democratic nature and absolute law. These four pillars should work together otherwise polarization or fragmentation would be inevitable for both the states and the international environment. Here the main point is not only that you have these values but also how you interoperate these values as part of an apparatus against terrorism.

Since social responsibilities of the states have been hampered by contemporary versions of laissez-faire/"free market" conservatism, we are not to skip the chances and opportunities to drainage the swap of terrorism. Social policies would limit areas of operation of terrorism, as well as mass support to their ideologies. Therefore, as Ward ${ }^{49}$ noted we are to identify the fact that terrorists are not borne but shaped by the circumstances. 
Laicism, as one of the greatest inventions of modernity, has not been applicable with all its aspects yet. Neither the leading Western countries, nor the rest of the world are free of religious influence. Additionally, there covertly retains religious animosity deeply related with social wide phobias, so secularism could be an intermediate way for solution. Although laicism seems as the ultimate solution to overcome (so called) "religiously" inspired terrorism, social experience since the Illumination Age shows that laicism is not as easily applicable as secularism. Considering the dramatic differences between these two concepts, secularism could help to overcome "religion" motivated terrorism to some extent when properly applied. ${ }^{50}$ Because of its institutions, nation state seems to be the only organization that could apply secularism properly.

Democracy, when applied to societies which couldn't develop the merit of citizenship and couldn't rise the individual but members of a group smaller than nation, may easily turn to a race of holding the majority to eliminate opposition. Yet, it is the only way to cut public support to terrorist organizations. Democracy cannot be sustainable and cannot help masses to express their demands and choices in a liberal atmosphere embodied with consent unless values like respect, tolerance, morale, ethic and citizenship flourish. Those values are neither nation nor state oriented, but cannot be best grown in any form of socio-political organization other than nation state. This brings us to the point that nation-state fertilizes the ground for democracy which would diminish public support for violence and sympathetic approaches to terrorism.

By absolute law we mean morality, ethic and justice. In this context low provides a base for all who are against terrorism. We cannot detach ethics from the politics and the experience of terrorism. $9 / 11$ is an experience which demands that we comprehend the deeper ethical questions. ${ }^{51}$ The moral injunction is joined by Michael Ignatieff. ${ }^{52}$

"In the age of terrorism, the temptations of ruthlessness can be overwhelming. But we are pulled in the other direction, too, by the anxiety that a violent response to violence makes us morally indistinguishable from our enemies"

"All battles between terrorists and the state are battles for opinion, and in this struggle ethical justifications are critical, to maintain the morale of one's own side, to hold the loyalty of populations who might otherwise align with terrorists, and to maintain political support among allies."

As an indispensable part of the sovereignty tripod, judiciary is essential for fight against terrorism. But judiciary which is not empowered by absolute law would not help to cut the support for terrorism, since it is related with the results not the reasons.

Fighting against terrorism in an environment embodied with laic stance, democratic nature and absolute law may give an impression that we fight with one hand tied behind our backs; this is illusive. One can easily wipe out terrorists by using counter-terrorist warfare but not the ideas behind it; that is, he cannot cut the "jugular vein" of terrorism. At this point, we come to the conclusion that the morality composed by social responsibility, democracy, freedom of belief and absolute law is the only effective tool to fight against terrorism in the long run, if the ingredients of this morality are applied effectively, seamlessly and efficiently in an interoperable way. These values could be best applied only by nation state.

\section{Conclusion}

The main discussion point of this paper is to illustrate the correlation among boosted globalization, weakened nation- states and globalized terrorism. 
In order to draw the parameters of level of analysis, one needs to underline the approaches and methodologies which explain the concept of globalization. But there are difficulties on theorizing the globalization concept, which stems from the problem of obtaining reliable information and the complexity of the concept. However approaches to globalization can be classified basically under four titles: 1) The Novelty Approach 2) The Flashback approach 3) The Permanency approach 4) The transformation approach. Comparing the specifications of these approaches we reach to the conclusion that the comprehensive and the transformation approaches give relatively more appropriate data to analyze the consequences of globalization from security perspective, than the other too deterministic and more holistic approaches.

Globalization, while setting its complex and amalgam structure, institutions and processes, has provoked instability by eroding the power of nation state and its capabilities to sustain tight control over means, resources, people and institutions that preserve security. Indeed, while globalization promotes standardization, global affinity, unity and intermingled interdependency on the one hand, it provokes localization, disparity and definition of identities on a smaller level than nation on the other hand. These aspects of the globalization also add to instability as well as decline in the power of nation state.

Global terrorism can spread due to the malign effects of globalization; the imbalance and vacuum of power; and disparity of players. All these three factors have created fragile environment for stability as well as fertile ground for terrorism. Failed states, minorities and separatists used terrorism to counterbalance the power gap or to consolidate their authority. Collapse of bipolar security environment and impoverishment of the nation-state as a consequence of globalization have exacerbated instability.

Terrorism with global influence is called global terrorism. Contemporary terrorism is global in nature since it uses advantages and exploits vulnerabilities of globalization and creates global effects. While the term global terrorism is not a new phenomenon, contemporary global terrorism requires new concept to fight against.

Any strategy against terrorism should consider all ingredients of globalization, assess the security environment and analyze the devices and processes to prevent global terrorism.

The imbalance of power between terrorism and nation state could result from either a dramatic impoverishment of the nation state or an extraordinary power gain of terrorism to an extent which differentiated its regular form. The complementary possibility is the situation in which both occurred simultaneously. The ascending trend of terrorism incidents verifies that as a consequence of globalization, nation state weakened and terrorism mutated to a more warfare kind.

9/11 terrorist attacks should be considered as the decision point to identify this new form of terrorism, which has no time and geographic limit and means and which is also backed by the masses. Developments after 9/11 terrorist attacks have taught us that we cannot overcome global terrorism by either using the way they understand or by negotiating with criminals against humanity (core elements of terrorist organizations), but separating "fish" from "water".

Terrorism first and foremost should be isolated from its integral parts, such as public support, financial power, abilities to exploit globalization etc. The most reliable force to properly respond to global terrorism is social, democratic, laic and lawful nation states. Basic identities of nation state could be used in such a way to impoverish global terrorism. 
Sertif Demir \& Ali Bilgin Varlık

\section{Notes}

${ }^{1}$ David Held and Anthony McGrew, "The Great Globalization Debate: An Introduction", in The Global Transformations Reader, D.Held and A.McGrew (Eds) (Malden USA: Polity Press, 2000), 1-45.

${ }^{2}$ For example, supporters of globalization consider it as the ultimate reach of civilization while the opponents define globalization as the new form of capitalism and imperialism. Some put more emphasis on information flow and define emergent global economy and culture as a "network society" grounded in new communications and information technology (See, Manuel Castells, The Rise of the Network Society (Oxford: Blackwell, 2010). Some frames globalization with its economic, cultural and political dimensions (See, Stanley Hoffmann, "The Clash of Globalizations", Foreign Affairs (July/August, 2002), 107). Some put more values on scientific and technological characteristics of globalization. Some see globalization merely as universalization of consumerism (See, Leslie Sklair, The Transnational Capitalist Class (Cambridge: Blackwell Publishers, 2001) while others stress on "the clash of civilizations" (See, Samuel Huntington, The Clash of Civilizations and the Remaking of World Order (New York: Touchstone Books, 1996).

${ }^{3}$ As one of the most famous writers of this approach, (Thomas L. Friedman, The Lexus and the Olive Tree (USA: Farrar, Straus and Giroux, 1999), 1-27) proposes that globalization is an international system, which replaced the old Cold War system, but he says hardly few about historical development of globalization. Although he has developed his theory and added historical background in his study "The World is Flat" (The World is Flat: A Brief History of The Twenty-First Century (USA: Farrar, Straus \& Giroux, 2005), 19), this helped little to his conceptual framework and less persuasion for severe criticism on his theory.

${ }^{4}$ Hardt and Negri (Empire, (London: Rvard University Press, 2000) present globalization as a complex process that involves a multidimensional mixture of expansions of the global economy and capitalist market system, new technologies and media, expanded judicial and legal modes of governance, and emergent modes of power, sovereignty, and resistance (Quoted from Douglas Kellner, Globalization, Terrorism, and Democracy: 9/11 and its Aftermath, (2002), 10. accessed: March 05, 2012), http://gseis.ucla.edu/faculty/kellner/essays/globalizationterroraftermath.pdf.

${ }^{5}$ Ali Bilgin Varlık, Küreselleşme ve Küreselleşmenin Orta Doğu'ya Etkileri (Globalization and Its Effects on the Middle East) (Ankara University, Faculty of Political Sciences, Unissued Phd Thesis, 2009), 19.

Although classification of ideas contains all forms of inefficiencies of being holistic, it makes easy to understand. For this reason the classification we suggested here is broader than the commonly used "against for" type. The classification made by Held and McGrew (The Global Transformations Reader (Malden USA: Polity Press, 2000), 1-45.) is also acceptable but not satisfactory enough to conceptualize the subject. The classification could be summarized as follows: 1) The Hyperglobalists 2) Skeptics 3) Transformationalist.

${ }^{6}$ Jean Baudrillard, Symbolic Exchange and Death (London: Sage, 2006), 1-3.

${ }^{7}$ Francis Fukuyama, The End of History and The Last Man (New York: Free Press, 1992), xx-xxi.

${ }^{8}$ See, Duncan Bell S.A., "History and Globalization: Reflections on Temporality", International Affairs 79/4 (2003): 801.

9 According to Hirst and Thompson (Globalization in Question: The International Economy and the Possibilities of Governance, (Cambridge: Polity Press, 2000), 9), during the 1870-1914 Belle Époque economic era the world economy was almost totally globalized. Today we are just about to reach the level of those days' economic openness. For example, current French economy has not reached yet to the economic openness level of 1913 which had the ratio of $35.4 \%$. The situation is the same for today's huge economies like Germany and Japan. Starting from 1970, although world economy has enormously grown, there has occurred a considerable gap between GDP's and the trade level.

${ }^{10}$ Furkan Y. Şen, Globalleşme Sürecinde Milliyetçilik Trendleri ve Ulus-Devlet (Ankara: Yargı Yayınevi, 2004), 181.

${ }^{11}$ See, Kevin Robins and Frank Webster, Times of the Technoculture (London and New York: Routledge, 1999), 4, 5.

${ }^{12}$ See, Immanuel Wallerstein, The End of the World As We Know It: Social Science for the Twenty-first Century (Minneapolis: University of Minnesota Press, 1999). Also see, Immanuel Wallerstein, World-Systems Analysis: An Introduction (USA, Duke University Press 2005). 
${ }^{13}$ N.Kenneth Waltz, "Globalization and American Power", The National Interest, (Spring 2000), 47-49, accessed Jan 10, 2011 (as of April 01, 2012 no longer available). http://findarticles.com/p/articles/mim2751/ is2000Spring/ai61299041.

${ }^{14}$ David Held, McGrew Anthony, Goldblatt David and Perraton Jonathan "Rethinking Globalization", in Global Transformations Reader, D.Held and A.McGrew (eds.) (Cambridge: Polity Press, 2000), 54-61.

${ }^{15}$ Robert O. Keohane and Joseph S. Nye, "Power and Interdependence", Survival: Global Politics and Strategy, The Center for International Affairs, Harvard University, 15/4 (1973): 160.

${ }^{16}$ Varlık, "Küreselleşme", 121.

${ }^{17}$ E. Joseph Stiglitz, Globalization and Its Discontents (USA W.W: Norton \& Company, 2002), 9.

18 William I. Robinson, Capitalist Globalization and the Transnationalisation of the State, Historical Materialism and Globalization in M. Rupert\&H. Smith (Eds), (London: Routledge, 2002), 210; Ray Kiely, "The Changing Face of Anti-Globalization Politics: Two (and a Half) Tales of Globalization and AntiGlobalization", Globalizations II/ 1 (May 2005): 135.

${ }^{19}$ William I. Robinson, "Social Theory and Globalization: The Rise of the Transnational State", Theory and Society 30 (2001): 182-191; Ray Kiely, "The Changing Face of Anti-Globalization Politics: Two (and a Half) Tales of Globalization and Anti-Globalization", Globalizations II/1 (2005): 135.

${ }^{20}$ Jerry Kloby, Inequality, Power, and Development: Issues in Political Sociology (New York: Humanity Books, 2004), 165.

${ }^{21}$ Moving from the idea that globalization has weakened the nation state, Samir Amin (Capitalism in the Age of Globalization: The Management of Contemporary Society, (London and New York: Zed Books, 1997), 15) has defined globalization as "Imperial of Chaos".

${ }^{22}$ Alan Miller, "Globalization, Terror, and Ethics: A Human Rights Perspective?", Globalizations VI/1 (2009): 149 .

${ }^{23}$ Jamal R. Nassar, Globalization and Terror: The Migration of Dreams and Nightmares, (Lanham: MD, Rowman \& Littlefield, 2005): 18.

${ }^{24}$ Michael Waizer, Arguing About War, (USA:Yale University Press, 2004), 134.

${ }^{25}$ Alan M. Dershowitz, Why Terrorism Works: Understanding the Threat, Responding to the Challenge (New Haven and London: Yale University Press, 2002), 4.

${ }^{26}$ Alexander Spencer, "Questioning the Concept of 'New Terrorism", Peace Conflict \& Development, VIII/1 (2006), 1-33, www.peacestudiesjournal.org.uk

${ }^{27}$ Leonard Weinberg, Pedahzur Ami and Hirsch-Hoefler Sivan, "The Challenges of Conceptualizing Terrorism" Terrorism and Political Violence XVI/4 (2004), 786.

${ }^{28}$ Alexander Spencer, "Questioning the Concept of 'New Terrorism", 3 quoted from Leonard Weinberg et. al., "The Challenges of Conceptualizing Terrorism", 786.

${ }^{29}$ See, Roger T. Ames, Sun-Tzu: The Art of Warfare, Robert G. Henricks (ed.), (New York: Ballantione Books, 1993). and Samuel B. Griffith, Sun-Tzu: The Art of War (London and New York: Oxford University, 1971).

${ }^{30}$ The term "Market State" implies that the nation-state cannot successfully cope with contemporary challenges so we are entering the transition from one constitutional order to another -from nation state to the market state (Philip Bobbitt, Terror and Consent: The Wars for the Twenty-First Century (New York: Anchor Books, 2009), 86.

${ }^{31}$ Giovanni Arrighi, The Long Twentieth Century (London and New York: Verso, 1994), 70-79.

${ }^{32}$ The similar research was conducted by Alexander Spencer op. cit. using the same source (with unlike data) but reaching different conclusion. He clearly mentioned that when examining the data on international terrorism incidents, one finds that although the number of terrorist incidents has generally declined from the mid-1980s, the number of fatalities per incident has increased since the 1980s. Considering that 'new terrorism' supposed to have started in the 1990s, this increase of fatalities might not be directly linked to the phenomenon of "new terrorism' (Isabelle Duyvesteyn, "How New Is the New Terrorism?", Studies in Conflict \& Terrorism XVII/5 (2004):447-448). 
${ }^{33}$ Decision point: A point in space and time, identified during the planning process, where it is anticipated that the commander must make a decision concerning a specific course of action (APP-6: NATO Glossary of Terms and Definitions, Bruselles, NATO Standardization Agency (NSA), (2010): 2-d-2).

34 The first sign of the new form of terrorism was Alfres P.Murrah's Federal Building bombing in Oklahoma City on April 19, 1995. With its 168 victims, this was by far the deadliest terrorist attack in American history until September 11, 2001 [Arnaud Blin, "The United States Confronting Terrorism", in The History of Terrorism: From Antiquity to AL Qaeda, Gerad Chaliand and Arnaud Blind (edts.) (Berkeley, Los Angeles, London: University of California Press, 2007), 407].

${ }^{35}$ Stuart Elden, Terror and Territory: The Spatial Extent of Sovereignty (USA, University of Minnesota Press, 2009), Xvii.

${ }^{36}$ Ibid, 2.

${ }^{37}$ O’Neill classifies public support as active and passive, and external support as moral, political, material, and sanctuary. (Bard O’Neill, Insurgency and Terrorism: From Revolution to Apocalypse, (Washington D.C.: Potomac Books, 2005), 94, 142).

${ }^{38}$ Walter Laqueur, The Age of Terrorism (Boston: Little, Brown, 1987), 91.

39 Religiously motivated terrorist organizations are becoming more common. According to the RAND-St Andrews University Chronology of International Terrorism, in 1968 none of the identified international terrorist organizations could be classified as 'religious'; in 1980, in the aftermath of the Iranian Revolution, there were two (out of sixty-four), and that number had expanded to twenty-five (out of fifty-eight) by 1995 (Richard Whelan, Al-Qaedaism: the Threat to Islam, the Threat to the World (Dublin: Ashfield Press, 2005), 23.

40 Jonathan R. White, Terrorism and Homeland Security. (Australia, Brazil, Japan, Korea, Mexico, Singapore, Spain, United Kingdom, United States: Wadsworth Press, 2009), 275.

${ }^{41}$ Kellner, "Globalization, Terrorism, and Democracy", 16.

42 Ibid, 23.

43 Ian Ward, Law, Text, Terror (Cambridge, New York, Melbourne, Madrid: Cambridge University Press, 2009), 175.

44 JP 3-24: Counter Insurgency Operations, USA, Joint Chief of Staff (2009), III-12.

45 It is attributed that the term "fish out of water" as a strategy on counter-insurgency was first used by Mao Zedong (or Tse-tung), who resembles fish to guerrilla and water to the people, in his study on guerrilla warfare "On the Protracted War".

${ }^{46}$ Alexander Spencer, "Questioning the Concept of 'New Terrorism”, 1-33.

${ }^{47}$ In order to end terrorism, Audrey Kurth Cronin (How Terrorism Ends: Understanding the Decline and Demise of Terrorist Campaigns, (U.K: Princeton University Press, 2009), 9) suggest broader strategy which covers six measures: 1) Capture or killing the group's leader 2) Entry of the group into a legitimate political process 3) Achievement of the group's aims 4) Implosion or loss of the group's public support 5) Defeat and elimination by brute force 6) Transition from terrorism into other forms of violence. Other studies on defeating terrorism include similar strategies. The common denominator of these strategies is cutting public support to terrorism.

${ }^{48}$ Center of Gravity: Characteristics, capabilities or localities from which a nation, an alliance, a military force or other grouping derives its freedom of action, physical strength or will to fight (APP-6, 2-c-3)

${ }^{49}$ Ward, "Law, Text, Terror", 179.

${ }^{50}$ Many varieties and forms of secularization have set in motion predominantly because of different historical processes (Elizabeth Shakman HURD, The Politics of Secularism in International Relations (Princeton: Princeton University Press, 2008), 15).

${ }^{51}$ Ward, "Law, Text, Terror", 175.

52 Michael Ignatieff, The Lesser Evil: Political Ethics in an Age of Terror (Princeton and Oxford: Princeton University Press, 2004), 1-9. 